\title{
WHY LAWYERS SHOULD NOT BE MANDATED REPORTERS OF CHILD ABUSE
}

\author{
MATTHEW ATKINSON*
}

This article comments on Vanessa Deverson's article in this volume entitled 'Child Abuse and Neglect: Mandatory Reporting and the Legal Profession' which argues that lawyers should be mandated to report suspected child abuse and neglect. It argues that lawyers should not be required to report suspicions of child abuse or neglect. Part I offers a reflection on Deverson's argument and Part II offers guidance on how lawyers should proceed in a responsible and ethical manner when confronted with child abuse and neglect.

\section{CONTENTS}

Introduction 123

I Reflection on Whether Lawyers Should Be Mandated Reporters ... 124

A Brief Overview of Mandatory Reporting Laws 124

B Legal Privilege, Confidentiality and Mandatory Reporting 125

C Respecting a Child's Wishes and Mandatory Reporting. 127

\section{INTRODUCTION}

Vanessa Deverson argues in the primary article that lawyers should be mandated to report suspected child abuse and neglect and contends that this mandate should prevail over the doctrine of legal privilege and the duty to maintain client confidentiality. ${ }^{1}$ Deverson maintains that the public interest in protecting innocent, vulnerable children necessitates diluting the doctrine of legal privilege and client confidentiality through changes to child protection

* $\quad$ BBUS (Northern Territory University), LLB/LP (Hons) (Flinders University); Managing Solicitor: Legal Advice Clinic, School of Law, University of South Australia.

1 Vanessa Deverson, 'Child Abuse and Neglect, Mandatory Reporting and the Legal Profession’ (2016) 2 University of South Australia Student Law Review 102. 
legislation. This comment argues that the law should not be changed and that lawyers should not be required to report suspicions of child abuse or neglect. Part I reflects upon Deverson's argument that lawyers should be mandated reporters in order to protect children. Part II offers guidance on how lawyers should proceed in a responsible and ethical manner when confronted with child abuse and neglect.

\section{REFLECTION ON WHETHER LAWYERS SHOULD BE MANDATED REPORTERS}

\section{A Brief Overview of Mandatory Reporting Laws}

Generally, child abuse and neglect occurs behind closed doors and most children are unable to protect themselves. ${ }^{2}$ Mandatory reporting laws are intended to break the silence that permeates the tragedy of child abuse and neglect. These laws require members of certain occupations including the police, teachers and healthcare professionals to report to an authority their suspicion of child abuse and neglect. ${ }^{3}$ Mandatory reporting laws commenced in the 1960s in the USA, and comparable legislation has subsequently been adopted in many countries. ${ }^{4}$ Mandatory reporting laws are in place across Australia, with South Australia being the first state to introduce such legislation in $1969 .{ }^{5}$ Since this time, most states have expanded mandatory reporting laws; the range of occupations required to report and the definition of what constitutes child abuse and neglect has expanded. ${ }^{6}$ While there is debate about the efficacy of mandatory reporting laws, ${ }^{7}$ the evidence suggests that such laws are effective. ${ }^{8}$

Robust debate is provoked when the doctrine of legal privilege, client confidentiality and the concomitant possibility of silence is weighed against

2 South Australia, Child Protection Systems Royal Commission, Child Protection Systems Royal Commission Report (2016) 114.

Ibid 116.

$4 \quad$ Ibid 114

5 Ibid.

6 Commonwealth, Royal Commission into Institutional Responses to Child Sexual Abuse, Mandatory Reporting Laws for Child Sexual Abuse in Australia: A Legislative History (2014) 9-17.

7 Alexia Takis, 'The Mandatory Reporting Debate' (2008) 8 Macquarie Law Journal 125.

8 South Australia, Child Protection Systems Royal Commission, Child Protection Systems Royal Commission Report (2016) 117. 
the perversion of child abuse and neglect. ${ }^{9}$ Like Deverson, Katharyn Christian argues that lawyers should be included as an occupation subject to mandatory reporting laws. ${ }^{10}$ Christian points out that '[w]hile including attorneys as mandatory reporters undoubtedly puts legal doctrines to the test, child abuse is an area that encourages experimentation. ${ }^{11}$ Conversely, Megan Smith says that lawyers should not be mandated reporters. ${ }^{12}$ She argues that undermining the doctrine of legal privilege and client confidentiality 'may injure the children whom we are trying to protect. ${ }^{13}$

\section{B Legal Privilege, Client Confidentiality and Mandatory Reporting}

The doctrine of legal privilege is 'based on the public interest in maintaining the confidences of clients and the encouragement of full and frank disclosure between client and lawyer.' ${ }^{14}$ A lawyer cannot provide correct advice and professional representation without being fully informed by their client; a client fearful of their lawyer disclosing their confidences may be discouraged from providing full and frank disclosure of their circumstances. Hence, legal privilege and the associated ethical duty to protect client confidentiality are sacrosanct: proper resolution of legal problems depends on it. The High Court of Australia has determined that legal privilege must not be judicially 'exorcised' by a competing public interest that requires disclosure of confidential lawyer client communication. ${ }^{15}$ Deane $\mathrm{J}$ has explained that legal privilege is vital in that it:

represents some protection of the citizen - particularly the weak, the unintelligent and the ill-informed citizen - against the leviathan of the modern state. Without it, there can be no assurance that those in need of independent legal advice to cope with the demands and intricacies of modern law will be

9 See, eg, Megan M Smith, 'Causing Conflict: Indiana's Mandatory Reporting Laws in the Context of Juvenile Defense’ (2014) 11 Indiana Health Law Review 439; Adrienne Jennings Lockie, 'Salt in the Wounds: Why Attorneys Should Not Be Mandated Reporters of Child Abuse' (2006) 36 New Mexico Law Review 125; Katharyn I Christian, 'Putting Legal Doctrines to the Test: The Inclusion of Attorneys as Mandatory Reporters of Child Abuse' (2008) 32 Journal of the Legal Profession 215.

10 Christian, above n 9, 217.

11 Ibid 236

12 Smith, above n 9, 439.

13 Ibid 477

14 Ysaiah Ross and Peter MacFarlane, Lawyers' Responsibility and Accountability Cases, Problems \& Commentary (Lexis Nexis Butterworths, 2012) 507.

15 Grant v Downs (1976) 135 CLR 674, 685 (Stephen, Mason and Murphy JJ). 
able to obtain it without the risk of prejudice and damage by subsequent compulsory disclosure...16

This point about legal privilege sits uncomfortably with Deverson's conclusion that lawyers should be mandated reporters of suspected child abuse and neglect. Giving lawyers this role means that legal advice cannot be provided independent of child protection authority oversight. A child protection authority is an agent of the modern state empowered to make decisions about what is in the best interests of the child, but there is no guarantee that intervention will yield a positive outcome. A child's best interest is a complex, indeterminate concept that is subject to a decision maker's broad discretion and personal values. ${ }^{17}$ Child protection authorities make difficult decisions where evidence may be ambiguous, distorted or circumstantial. ${ }^{18}$ One of the most traumatising events for a child and parents is compulsory removal of a child from their family, ${ }^{19}$ and child protection authority intervention is not free from criticism. In Re Georgia and Luke [No 2] ${ }^{20}$ the Court ordered that two children be immediately returned their parents after the Department of Community Services failed to produce any substantive evidence for their decision to remove two young children from their home. Palmer $\mathbf{J}$ stated that the action taken by the Department was an abuse of power that resulted in 'young children [being removed] from the care of good and nurturing parents for the last twelve weeks. ${ }^{21}$ Deverson's conclusion that lawyers must be mandated reporters is unsettling when it is juxtaposed against this context. It unsafely assumes that child protection authority intervention is always preferable irrespective of the client's circumstance or intention in seeking independent legal advice.

In the context discussed above, there are two plausible possibilities if lawyers are to be mandated reporters of child abuse and neglect. The first is that full and frank discussion with lawyers may be impaired; an individual, especially

16 Bakerv Campbell (1983) 153 CLR 52, 120.

17 Bernd Walter, Janine Alison Isengger, and Nicholas Bala, 'Best Interests in Child Protection Proceedings: Implications and Alternatives’ (1995) 12 Canadian Journal of Family Law 367; Steven Parker, 'The Best Interests of the Child - Principles and Problems' (1994) 8 International Journal of Law and the Family 26.

18 Tamara Walsh and Heather Douglas, 'Lawyers' Views of Decision-Making in Child Protection Matters: The Tension Between Adversarialism and Collaborative Approaches' (2012) 38(2) Monash University Law Review 181-2.

19 Ibid 181

20 Re Georgia and Luke (No 2) [2008] NSWSC 1387 (19 December 2008).

21 Ibid [74]. 
someone who is at risk of coming under the scrutiny of the child protection system, will likely withhold information from their lawyer. The second is that an individual may be discouraged from seeing a lawyer because they fear significant trauma from child protection authority intervention. Neither possibility is desirable in promoting access to justice - at best, a person loses entitlement to proper legal advice and representation, and at worst, a person forgoes entitlement to a lawyer. ${ }^{22}$ Furthermore, parents and children in or at risk of entering the child protection system are typically marginalised from the wider community. Drug addiction, homelessness, poor mental health, intellectual disability and reliance on social security are prominent issues in child protection matters. ${ }^{23}$ Persons with social and economic disadvantage tend to face a greater number of legal problems than those who do not face such marginalisation. ${ }^{24}$ If making lawyers mandated reporters results in marginalised people being fearful of seeking legal advice, this will only exacerbate social and economic disparity. ${ }^{25}$ This in turn is harmful for children.

\section{Respecting a Child's Wishes and Mandatory Reporting}

Mandating lawyers to report suspected child abuse and neglect assumes that all children are unable to make decisions that are in their own best interests. This assumption is problematic, particularly for lawyers who represent older children. ${ }^{26}$ As an example, ${ }^{27}$ consider a case where a teenager charged with theft tells his lawyer that his wrongdoing has come about because things have been tough at home. He says that his alcoholic step-father has been hitting him and that they have had a number of physical altercations. When the lawyer talks about reporting the matter to the police and the child protection authority, the child refuses. He says he does not want to get them involved. He fears being separated from his mum and being put into foster care. He says that he wants to stay in the same high school and graduate with his friends. However,

22 Smith, above n 9, 456-7.

23 Tamara Walsh and Heather Douglas, 'Lawyers, Advocacy and Child Protection' (2011) 35 Melbourne University Law Review 621, 622-3.

24 Rebecca Sandefur, "What We Know and Need To Know about the Legal Needs of the Public (2016) 67 South Carolina Law Review 443, 446-7.

25 Peter Margulies, 'Lawyering for Children: Confidentiality Meets Context' (2007) 81 St John's Law Review 601, 638-9.

26 I consider the position of younger children in Part II.

27 This example is adapted from a client interview discussed in Alexis Anderson, Lynn Barenberg, and Paul R Tremblay, 'Professional Ethics in Interdisciplinary Collaboratives: Zeal, Paternalism, and Mandated Reporting' (2007) 13 Clinical Law Review 659, 715-6. 
when a lawyer is a mandated reporter in this situation, the client's instructions are ignored. The lawyer's report to a child protection authority will invariably damage the relationship, as the child's voice and knowledge do not matter. ${ }^{28}$ A child who is capable of determining their own best interest is put into an invidious position when lawyers are mandated reporters. Similar to the discussion above, the logical consequence is twofold. Children may not seek legal advice because they fear child protection authority intervention. Likewise, children may be deterred from disclosing abuse and neglect when interacting with lawyers who are legally obliged to report it. ${ }^{29}$ Both of these eventualities put a child at risk of further harm.

\section{RESPONDING ETHICALly TO CHILD ABUSE AND NEGLECT}

I am not convinced that we should change child protection laws to include lawyers as an occupation subject to mandatory reporting requirements. However, I do not suggest that lawyers should ignore or remain silent to evidence of child abuse and neglect. Of course, when a lawyer is satisfied that a child is at risk of imminent serious harm, disclosure to police and child protection authorities should be made irrespective of the client's wishes. ${ }^{30}$ Likewise, the absence of imminent serious harm does not excuse lawyers from responding to suspicions of child abuse and neglect when dealing with clients. Lawyers who fail to respond properly are potentially breaching their fundamental ethical duty to act in their client's best interests. ${ }^{31}$ They are required to 'assist a client to understand relevant legal issues and to make informed choices about action to be taken during the course of a matter. ${ }^{32}$

When lawyers are confronted with evidence of child abuse and neglect they should enter into a productive dialogue about it with their client. Indeed, ethical lawyering entails the provision of an objective viewpoint and helping the client to make an informed choice in order to promote their best interests. ${ }^{33} \mathrm{~A}$ client's best interests cannot be advanced by their being unaware of actions that can prevent child abuse and neglect or otherwise minimise risk of its occurrence. So, returning to the example above, the lawyer should help their young client

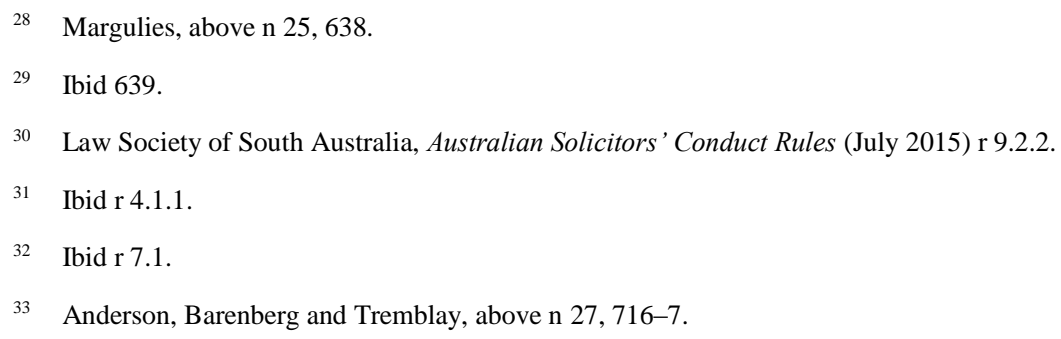


to identify all options to achieve the objective of staying in the home while not losing sight of the paramountcy of personal wellbeing. This dialogue may canvas matters including the accessibility of alternative accommodation when needed, and identifying appropriate resources that will assist the client to safely live with his mum and stay in the same high school.

This dialogue between the lawyer and the client reflects an ethics of care approach. ${ }^{34}$ The lawyer's focus is on 'the best interests of both the client and others in a holistic way that incorporates the moral, emotional, and relational dimensions of a problem into the legal solution. ${ }^{35}$ This approach is preferable to a lawyer being mandated to report suspected child abuse and neglect irrespective of circumstance. An ethics of care approach is jeopardised when a lawyer is a mandated reporter. The type of dialogue outlined above is either rendered redundant because the lawyer client relationship sours or the child protection authority intervenes in a way that does not reflect the client's wishes. Alternatively, the dialogue never occurs because the client is not willing to disclose or see a lawyer who is a mandated reporter of child abuse and neglect.

Unlike Deverson, I am not persuaded that lawyers should be mandated reporters of child abuse and neglect. I fear that the consequence of giving lawyers this role may result in the opposite of what mandated reporting is intended to achieve - protecting children from abuse and neglect. Making lawyers mandated reporters might discourage people from seeking legal advice and speaking to lawyers about matters relating to child abuse and neglect. Creating such barriers to access justice only serves to exacerbate economic and social disparity. These results are undesirable, and potentially harmful for children. In responding to child abuse and neglect, lawyers should adopt an ethics of care approach by engaging in dialogue with their client so that an appropriate response to child abuse and neglect can take place.

34 Christine Parker, 'A Critical Morality for Lawyers: Four Approaches to Lawyers' Ethics' (2004) 30 Monash University Law Review 49.

35 Ibid 70. 